\title{
Opplysninger om arvelig disposisjon ved søknad om helseforsikring
}

\author{
Forsikringsselskaper og andre instanser utenfor helsevesenet har ikke lov til å be om, motta, besitte eller \\ bruke informasjon som er fremkommet ved genetiske undersøkelser eller systematisk kartlegging av arvelig \\ sykdom i en familie. Rådet for legeetikk mener at dagens regelverk er uklart og inkonsekvent. Inntil nærmere \\ avklaring foreligger kan forsikringssøkere unnlate å opplyse om behandling som er basert på prediktiv testing.
}

Trond Markestad

trond.markestad@helse-bergen.no

Rådet for legeetikk

Den norske legeforening

Rådet for legeetikk ble for en tid tilbake bedt om å vurdere hvordan en forsikringssøker som fikk medikamentell behandling pga. en arvelig sykdomsdisposisjon påvist ved gentest og hans lege skulle forholde seg til et forsikringsselskaps krav om helseopplysninger. Undersøkelsen var gjennomført som ledd i en familiekartlegging etter at en slektning døde av tilstanden. Dilemmaet var at forsikringssøkeren ble bedt om å oppgi hvilke medisiner han brukte samtidig som forsikringsselskapet ikke har lov til å be om opplysninger fra gentester.

Rådet har tidligere påpekt dette dilemmaet - at det er forbudt å oppgi helserisiko fremkommet ved gentesting og kartlegging av familiehistorie, mens forbudet ikke gjelder for andre former for prediktive tester, slik som for eksempel måling av blodtrykk og bestemmelse av blodlipider og kroppsmasseindeks. Rådet for legeetikk ba Bioteknologinemnda og Helsedirektoratet om å vurdere hvordan et slikt dilemma bør håndteres ut fra gjeldende regelverk.

\section{Bioteknologinemndas syn}

Bioteknologinemnda påpekte at det ifølge bioteknologiloven er forbudt for forsikringsselskaper å be om, motta, besitte eller ta i bruk informasjon om genetisk status fra genetisk testing, uansett hvordan dette fremkommer (1). Genetiske undersøkelser omfatter også presymptomatiske og prediktive undersøkelser og undersøkelser for å påvise bærertilstand. Forbudet gjelder også kartlegging av familiehistorie og «organundersøkelser som har til hensikt å gi informasjon om menneskers arveegenskaper» (§ 5.1). Forsikringssøker har dermed heller ingen plikt til å informere forsikringsselskapet om helseopplysninger som er fremkommet på slikt grunnlag.
Imidlertid sier retningslinjer hos forsikringsselskaper (gjennom Finansnæringens Hovedorganisasjon) at det kan spørres om arvelige sykdommer hos foreldre og søsken ved søknad om forsikring for kritisk sykdom (2). Dette gjelder forsikring med engangsutbetaling for en definert gruppe alvorlige sykdommer og ved forsikring for død og uførhet hvis det dreier seg om høye forsikringssummer.

I bioteknologiloven er det ikke spesifisert hvordan helseopplysninger som ikke hører under definisjon av genetisk undersøkelse, men som indirekte gir slik informasjon (f.eks. bruk av medikamenter og profylaktisk kirurgi) skal behandles. Bioteknologinemnda påpekte også at det er problematisk å oppgi et medikament som tas på grunn av en prediktiv test, ettersom forsikringsselskapet ikke har lov til å etterspørre opplysninger som indirekte viser at det er foretatt en genetisk test. På den annen side er det uansett forbudt for et forsikringsselskap å ta hensyn til eller diskriminere forsikringssøker på grunnlag av en prediktiv gentest (forsikringsavtaleloven $\S 12-12$ ) (3). Dette kan kontrolleres av forsikringssøker, ettersom et eventuelt avslag eller begrensing av en helseforsikring skal begrunnes.

Rådet for legeetikk hadde foreslått tre mulige løsninger:

- Forsikringssøker lar være å oppgi medikamentet

- Forsikringssøker oppgir medikamentet, men presiserer at det tas på grunn av en prediktiv gentest og ikke på grunn av sykdom - da har ikke forsikringsselskapet lov til å ta hensyn til det

- Forsikringssøker oppgir medikamentet, men legen skriver i sin vurdering at det tas på grunnlag en prediktiv gentest da har ikke forsikringsselskapet lov til å ta hensyn av det

Bioteknologinemnda mente at ingen av disse alternativene oppfyller kravene $\mathrm{i}$ både bioteknologiloven og forsikringsavtaleloven. De påpekte også at dette sannsynligvis bare er ett eksempel på en problemstilling som vil bli mer vanlig i fremtiden, for eksempel ved at mennesker settes på medikamenter, får utført bildediagnostikk (f.eks. mammografi utenom vanlig rutine) eller profylaktisk kirurgi på grunnlag av risikovurderinger basert på prediktive gentester, ikke fordi de har symptomer eller påvist sykdom.

I dag får personer som vurderer prediktiv gentesting informasjon om dette og anbefales, hvis de har ment å tegne helseforsikring, å gjøre dette i forkant av undersøkelsen for å unngå å komme i et praktisk og moralsk dilemma.

Bioteknologinemnda påpekte i sin konklusjon at bioteknologiloven er uklar på dette punktet og ville anmode Helse- og omsorgsdepartementet om å gi en tolking og å utarbeide praktiske råd/retningslinjer til personer som vurderer prediktiv gentesting, og til helsepersonell og forsikringsselskaper om håndtering av helseopplysninger som indirekte viser at forsikringssøker har fått utført en prediktiv gentest.

\section{Helsedirektoratets syn}

Helsedirektoratet bekreftet Bioteknologinemndas forståelse om begrensningene i å bruke informasjon fremkommet gjennom genetisk testing (bioteknologiloven $\S 5-8$ ), men gjorde et poeng av å skille mellom prediktive/presymptomatiske tester og diagnostiske gentester. Dersom den genetiske undersøkelsen er utført som ledd i utredning av sykdom på grunn av symptomer (f.eks. dersom en person har fått utført gentest pga. gjentatte besvimelser), gjelder ikke forbudet i $§ 5-8$ mot at forsikringsselskapet innhenter og benytter opplysningene. Ellers pekte Helsedirektoratet på helsepersonelloven $\S 15$, 2. og 3. ledd, som gir retningslinjer for hvordan legen bør ta opp sensitiv informasjon med pasienten før dette utformes i en legeerklæring (4).

Helsedirektoratet poengterte at «forsikringsnæringens interesser må vike for bioteknologilovens viktige prinsipp om at teknologien skal benyttes med respekt for menneskeverdet og ikke-diskriminering av mennesker på grunn av arveanlegg», og at 


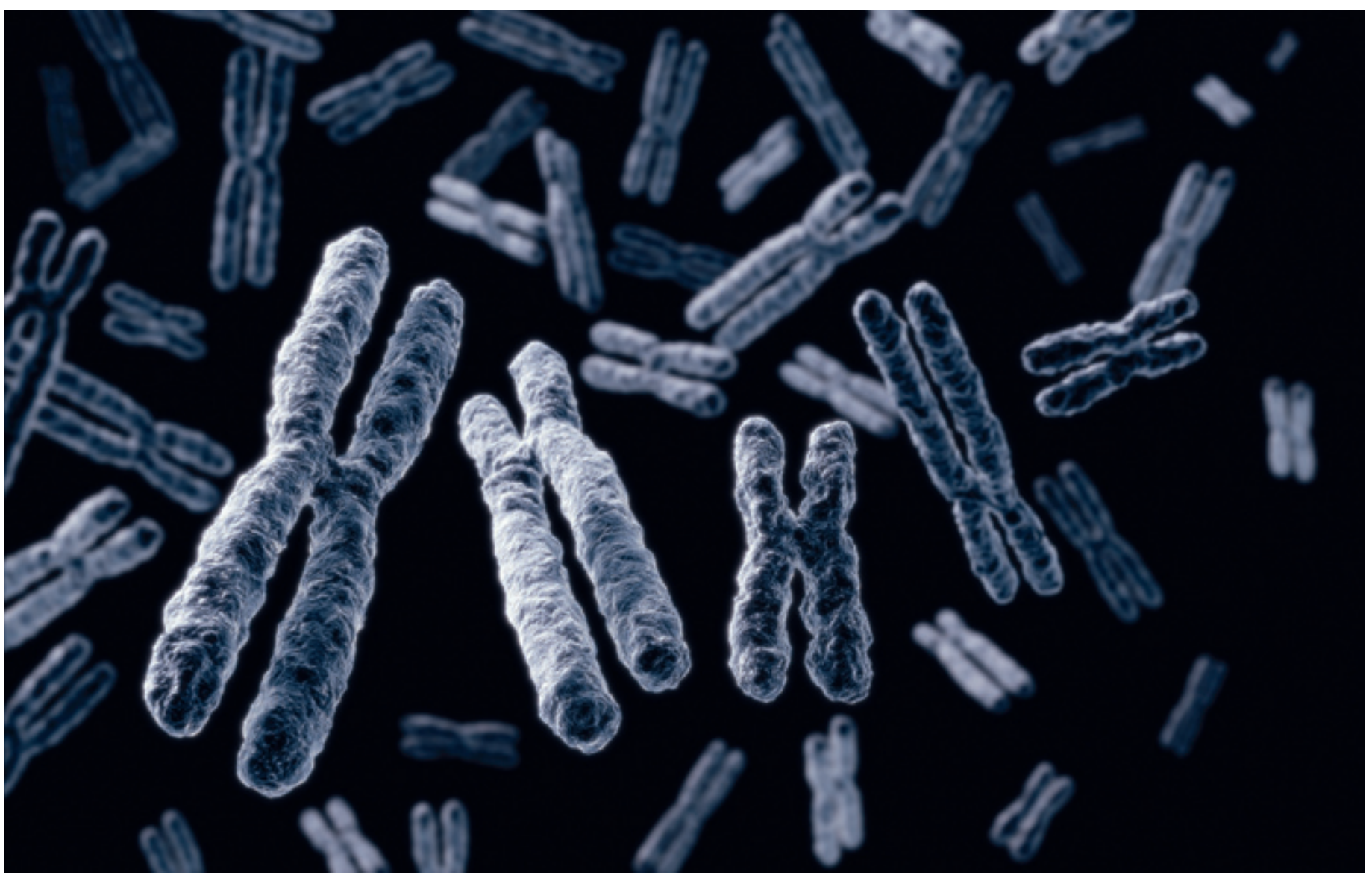

Illustrasjonsfoto Istockphoto

«forbudet i bioteknologiloven $\S 5-8$ gjelder dersom opplysningene er resultat av en prediktiv undersøkelse - altså i de tilfeller pasienten er uten symptomer, men det er påvist arvelig genetisk sykdom og personen er satt på forebyggende medikamenter». Rådet tolker dette slik at forsikringssøker bør anbefales ikke å gi opplysninger om medikamenter som tas på grunnlag av en prediktiv gentest.

Helsedirektoratet kommenterte ikke hvordan prediktive undersøkelser som ikke omfattes av bioteknologiloven $\S 5-8$, for eksempel måling av blodtrykk og blodnivå av kolesterol hos personer som ikke har symptomer på sykdom, bør behandles i forhold til søknad om helseforsikring.

\section{Rådets syn}

Rådet for legeetikk får ofte klager på leger fra forsikringsselskaper fordi disse i sine legeerklæringer ikke oppgir alle relevante opplysninger om en forsikringssøker. Samtidig opplever rådet at leger er usikre på hvor mye de bør opplyse om. Retningslinjer for hva en slik legeerklæring skal inneholde, er gitt i helsepersonelloven $\S 15 \mathrm{og}$ i Etiske regler for leger kapittel IV, § 4 (5). Erklæringene skal bare inneholde informasjon som er nødvendig for formålet, men relevante opplysninger må ikke forties eller fordreies. Erklæringen skal altså inneholde alle opplysninger som legen bør forstå er av betydning for mottakeren og for formålet.

Bioteknologiloven er imidlertid tydelig på at det ikke skal opplyses om arvelig risiko basert på prediktiv gentesting eller på kartlegging av arvelige faktorer gjennom familieanamnese til instanser utenom helsevesenet, for eksempel forsikringsselskaper. For å unngå et moralsk dilemma anbefaler både Bioteknologinemnda og Helsedirektoratet at den som vurderer prediktiv gentesting, informeres om dette og anbefales å tegne forsikring før gentesten tas dersom vedkommende vurderer å tegne en helseforsikring.

Rådet er enig i at det kan være praktisk å tegne en helseforsikring for man får kjennskap til egen helserisiko. Likevel må det ikke være slik at den som kjenner sin genetiske risiko, skal oppleve et større moralsk dilemma eller flere praktiske vansker enn den som har kunnskap og er så forutseende at han tegner forsikring før han vet noe om risiko. I så fall er retningslinjene mangelfulle, noe som også er påpekt av Bioteknologinemnda.

Dersom en prediktiv gentest eller familieanamnese har ført til et oppfølgings- eller behandlingsopplegg, må det ikke være opp til den enkelte forsikringssøker eller lege hvordan dette skal håndteres - ut fra egne moralske vurderinger. Ved prediktiv gentesting kan det også være usikkerhet om resultatet av gentesten, det vil si om personen som ble testet egentlig har økt risiko for sykdom eller ikke. Dessuten kan en forsikringssøker, og kanskje også legen, være usikker på eller ikke oppmerksom på om et resultat er fra en prediktiv test, en presymptomatisk test eller en diagnostisk test. Selv om det opplyses at en behandling er forebyggende og basert på resultatet fra en prediktiv test og derfor ikke skal ha betydning for forsikringsavtalen, er rådet bekymret for at opplysningen likevel vil bidra til avslag eller dyrere forsikring ved at andre helsemessige forhold som fremgår av søknaden, tillegges urimelig stor vekt.

Rådet mener derfor at Helse- og omsorgsdepartementet og Helsedirektoratet må utarbeide konkrete retningslinjer for hvordan informasjon som indirekte viser at forsikringssøkeren har fått påvist en helserisiko gjennom en prediktiv gentest eller familieanamnese, skal håndteres. Ingen metode synes ideell. Én mulighet er at søknadsskjemaet inneholder informasjon om at behandling på grunnlag av prediktive gentester og/eller familieanamnese ikke skal oppgis, men dette kan det være vanskelig for en søker å ha tilstrekkelig kunnskap om. En annen mulighet er at søker oppgir behandlingen og at legen opplyser at den er resultat av en prediktiv test, men da har allerede forsikringsselskapet fått en opplysning de ikke skal ha. 
Bioteknologilovens bestemmelse om at det heller ikke er lovlig å kartlegge arvelig risiko ut fra avdekking av familiehistorie står, etter rådets syn, i kontrast til Finansnæringens Hovedorganisasjons veiledning til forsikringsselskapene om at forsikringsselskapene «skal være tilbakeholdende med å spørre om arvelige sykdommer i familien. I dag stilles det spørsmål om foreldre eller søsken har bestemte arvelige sykdommer kun ved søknad om kritisk sykdom og forsikringer for død og uførhet hvis det er høye forsikringssummer involvert». Rådet vil også be Helse- og omsorgsdepartementet og Helsedirektoratet vurdere denne veiledningen opp mot bestemmelsene i bioteknologiloven.

Inntil nærmere avklaring foreligger mener Rådet for legeetikk at forsikringssøkere i samråd med sin lege kan unnlate å oppgi behandling som er basert på prediktiv testing. Dersom søkeren har opplyst om slik behandling, må legen i sin erklæring presisere forholdet.

Bioteknologiloven er en særlov som beskytter en person mot at opplysninger om arvelig disposisjon som kommer frem ved prediktiv eller presymptomatisk gentesting eller etter kartlegging av familiehistorie skal tas hensyn til, for eksempel ved søknad om privat helseforsikring. Det kan virke ulogisk at ikke andre prediktive undersøkelser, for eksempel måling av serum-kolesterol og blodtrykk, behandles på samme måte. Rådet etterlyser derfor en klarere avgrensning av hva som kan og ikke kan oppgis overfor instanser utenfor helsevesenet, for eksempel forsikringsselskaper. Et annet spørsmål som rådet finner uklart, er håndtering av presymptomatiske undersøkelser, for eksempel bildemessig påvisning av nyrecyster eller genetisk påvisning av Huntingtons chorea før personen har fått symptomer.

\section{Trond Markestad (f. 1945)}

er leder av Rådet for legeetikk. Han er barnelege, professor ved Universitetet i Bergen, forskningskoordinator ved Barneklinikken ved Haukeland universitetssykehus og forskningsrådgiver ved Sykehuset Innlandet. Ingen oppgitte interessekonflikter.
Litteratur

1. Lov om humanmedisinsk bruk av bioteknolog m.m. (bioteknologiloven). www.lovdata.no/all/ hl-20031205-100.html (22.2.2011).

2. Finansnæringens fellesorganisasjon. www.fnh.no/ no/Hoved/Fakta/Livsforsikring-og-pensjon/ (14.2.2011)

3. Lov om forsikringsavtaler (forsikringsavtaleloven). www.lovdata.no/all/nl-19890616-069.html (22.2.2011).

4. Lov om helsepersonell m.v. (helsepersonelloven) www.lovdata.no/all/nl-19990702-064.html (22.2.2011).

5. Etiske regler for leger. www.legeforeningen.no/id/ 485.1 (22.2.2011).

Mottatt 1.1.2011, første revisjon innsendt 14.2. 2011, godkjent 24.2. 2011. Medisinsk redaktør Petter Gjersvik. 